Review

\title{
Antitumor Peptides from Marine Organisms
}

\section{Lan-Hong Zheng ${ }^{1}$, Yue-Jun Wang ${ }^{1}$, Jun Sheng ${ }^{1}$, Fang Wang ${ }^{1}$, Yuan Zheng ${ }^{1}$, Xiu-Kun Lin ${ }^{2,3, *}$ and Mi Sun ${ }^{1, *}$}

1 Yellow Sea Fisheries Research Institute, Chinese Academy of Fishery Sciences, Qingdao 266071, China; E-Mails: zhenglanhong@126.com (L.-H.Z.); wangyj@ysfri.ac.cn (Y.-J.W.); shengjun01@hotmail.com (J.S.); wendywf2002@yahoo.com.cn (F.W.); zhengyuan@ysfri.ac.cn (Y.Z.)

2 Department of Pharmacology, Capital Medical University, Beijing 100069, China

3 Institute of Oceanology, Chinese Academy of Science, Qingdao 266071, China

* Authors to whom correspondence should be addressed; E-Mails: linxiukun@yahoo.com (X.-K.L.); sunmi0532@yahoo.com (M.S.); Tel.: +86-532-82898893 (X.-K.L.); +86-532-85819525 (M.S.); Fax: +86-532-82898916 (X.-K.L.); +86-532-85841193 (M.S.).

Received: 12 July 2011; in revised form: 8 September 2011 / Accepted: 22 September 2011 / Published: 10 October 2011

\begin{abstract}
The biodiversity of the marine environment and the associated chemical diversity constitute a practically unlimited resource of new antitumor agents in the field of the development of marine bioactive substances. In this review, the progress on studies of antitumor peptides from marine sources is provided. The biological properties and mechanisms of action of different marine peptides are described; information about their molecular diversity is also presented. Novel peptides that induce apoptosis signal pathway, affect the tubulin-microtubule equilibrium and inhibit angiogenesis are presented in association with their pharmacological properties. It is intended to provide useful information for further research in the fields of marine antitumor peptides.
\end{abstract}

Keywords: antitumor; peptides; marine organisms

\section{Introduction}

The sea, covering $70 \%$ of the Earth's surface, offers a considerably broader spectrum of biological diversity than terra firma. Containing approximately $75 \%$ of all living organisms, the marine environment offers a rich source of natural products with potential therapeutic application. The 
discovery of the bio-regulatory role of different endogenous peptides in the organism as well as the understanding of the molecular mechanisms of action about some new bioactive peptides obtained from natural sources on specific cellular targets, contributed to developing peptides as promising lead drug candidates. Recently, marine peptides have opened a new perspective for pharmaceutical developments [1].

Peptides discovered from marine organism induce cell death with different mechanisms, including apoptosis, affecting the tubulin-microtubule equilibrium, or inhibiting angiogenesis (Figure 1). This finding has increased our knowledge about new potent cytotoxic, and many other properties with novel chemical structures associated to original mechanisms of pharmacological activity. These facts introduce marine peptides as a new choice for obtaining lead compounds on biomedical research. This review will account for the progress of the recent years and provide novel information in this field.

Figure 1. Schematic depiction of major mechanisms for major antitumor peptides. Marine peptides induce cell death via the following pathways, apoptosis (1), affecting the tubulin-microtubule equilibrium (2) and angiogenesis pathway (3).

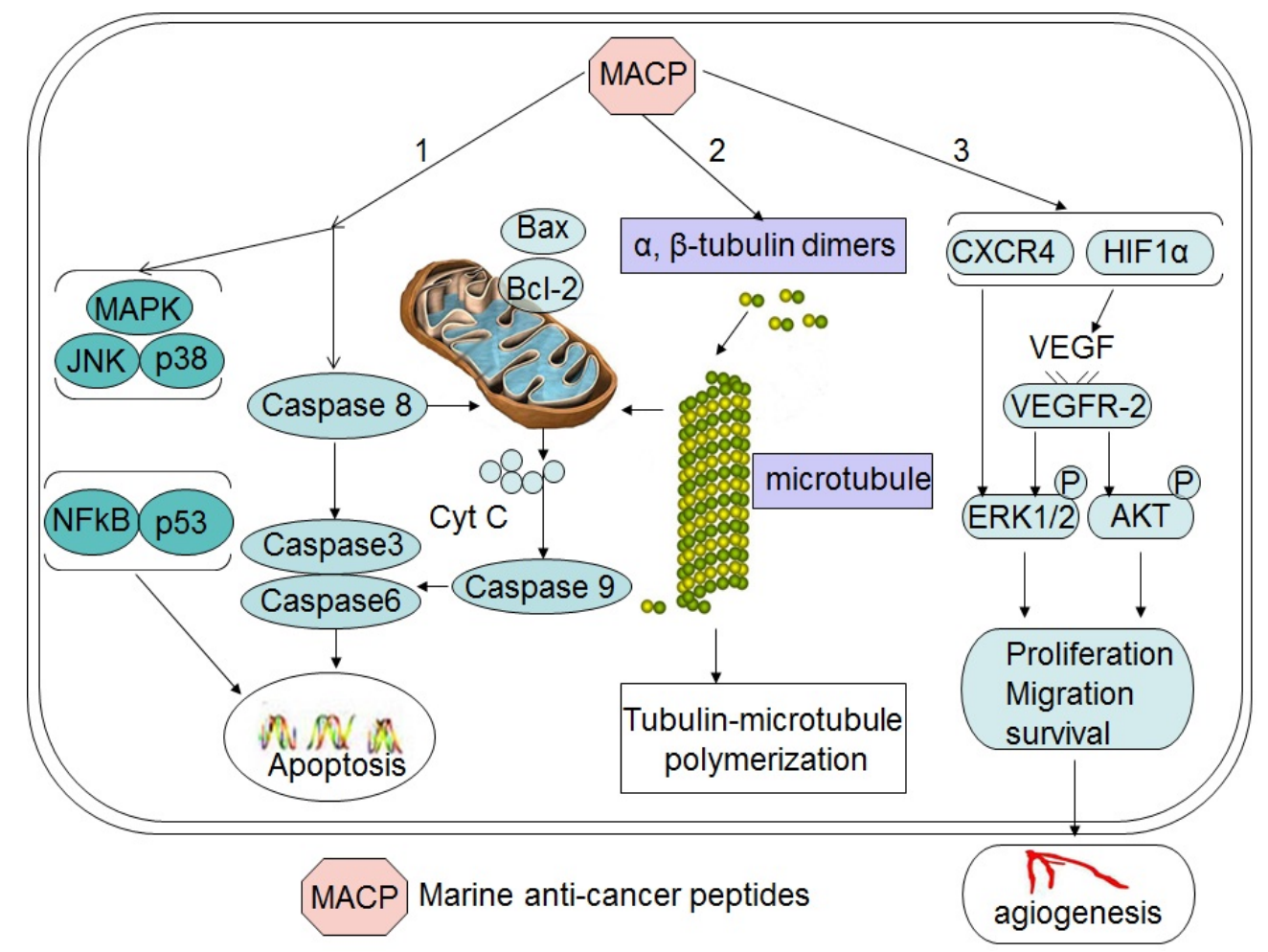

\section{Peptides that Induce Apoptosis}

Apoptosis as a form of programmed cell death is one of the major mechanisms of cell death in response to cancer therapies [2]. Also, apoptosis is a naturally occurring and evolutionarily conserved process by which cells that are no longer useful are directed to their deaths [3]. Apoptosis plays an indispensable role and is a fundamental process in development, physiology and homeostasis [4-7]. Its deregulation, i.e., either loss of pro-apoptotic signals or gain of anti-apoptotic signals, can lead to a variety of pathological conditions such as cancer initiation, promotion and progression or result in treatment failures $[8,9]$. As apoptosis does not usually trigger inflammatory or immune response, it 
becomes a preferable way of cancer cell death during cancer treatments. As such, modulation of apoptotic pathways and selective induction of apoptosis by chemical agents are likely to be a promising approach for cancer therapy [6,10-15]. In mammals, there are two major signaling systems that result in the activation of caspases, the extrinsic death receptor pathway [16-19] and the intrinsic mitochondrial pathway [20,21]. These two pathways include many cross talks between them. There is a long list of pro- or anti-apoptotic molecules that can trigger or regulate apoptosis. Therefore, developing anticancer peptides that target these molecules has become an important strategy for anticancer therapies.

Growing evidence shows that most marine anticancer peptides with cytotoxicity may trigger apoptosis by targeting many cellular proteins, and the induced apoptotic process involves both intracellular and extracellular pathways [14]. The balance between the pro-survival gene Bcl-2 and the pro-apoptotic gene Bax plays a key role in maintaining cell viability. Therefore, inhibition of Bcl-2 or induction of Bax becomes a good strategy for triggering an apoptotic process [22]. Identification of caspases activators becomes another approach for the discovery of novel anticancer agents because caspases are involved in intrinsic and extrinsic apoptosis pathways [23,24]. Some marine anticancer peptides can activate the Jun $N$-terminal kinase (JNK) and p38 mitogen-activated protein kinases (MAPK) pathways that lead to the release of cytochrome c (Cyt C) from mitochondria [25]. In brief, apoptosis is a complicated process and involves a huge number of signaling molecules, and failure of apoptosis activation is one of the major impediments to the treatment of cancer. Therefore, a good strategy for the development of new anticancer agents is to identify or develop such agents that can target multiple apoptosis regulating genes.

\subsection{Peptides that Activate the Intrinsic Mitochondrial Pathway}

The mitochondrial cell death pathway commences when apoptogenic molecules presented between the outer and inner mitochondrial membranes are released into the cytosol by mitochondrial outer membrane permeabilization. The release of pro-apoptotic factors such as cytochrome c from mitochondria leads to formation of a multimeric complex known as the apoptosome and initiates caspases activation cascades. These pathways are important for normal cellular homeostasis and play key roles in the pathogenesis of many diseases $[21,26]$. In the intrinsic mitochondrial pathway, at least 18 pro- and anti-apoptotic proteins of the Bcl-2 family are pivotal regulators of apoptosis, Bax as a proapoptotic member of the Bcl-2 family is very influential in the pro- and anti-apoptotic balance by regulating mitochondrial functions [22,27].

Jaspamide (Jasplakinolide), isolated from marine sponge Jaspis johnstoni, is a cyclic depsipeptide with a 15-carbon macrocyclic ring containing three amino acid residues (Figure 2A) [28]. Jasplakinolide induces apoptosis in Jurkat $\mathrm{T}$ cells as demonstrated by nucleosomal DNA ladder formation. Enhanced caspase-3 activity is also observed in Jaspamide-treated Jurkat $\mathrm{T}$ cells by using the fluorescent substrate DEVD-MAC. Transformed cell lines were more susceptible to Jasplakinolide-induced apoptosis than normal nontransformed cells [29]. Jaspamide-induced apoptosis is associated with caspase- 3 activation and a decrease in Bcl-2 protein expression, but also with increased Bax levels. It seems that jaspamide induces a caspases independent pathway of cell death, which is responsible for 
the observed cytoplasmic and membrane changes in apoptosing cells, and also a caspases-dependent cell death, which is responsible for PARP proteolysis [30].

Figure 2. Chemical structures of major marine peptides with apoptotic activity: Jasplakinolide (A), Somocystinamide A (B), Aplidine (C) and Didemnin B (D).

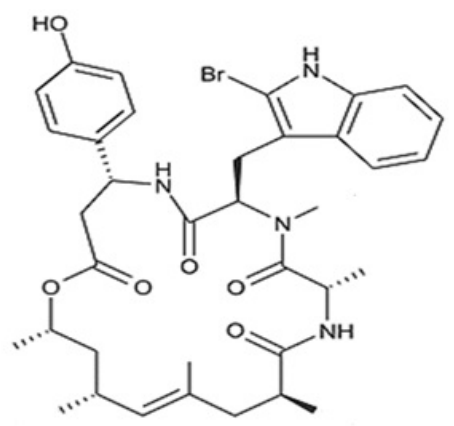

A. Jasplakinolide

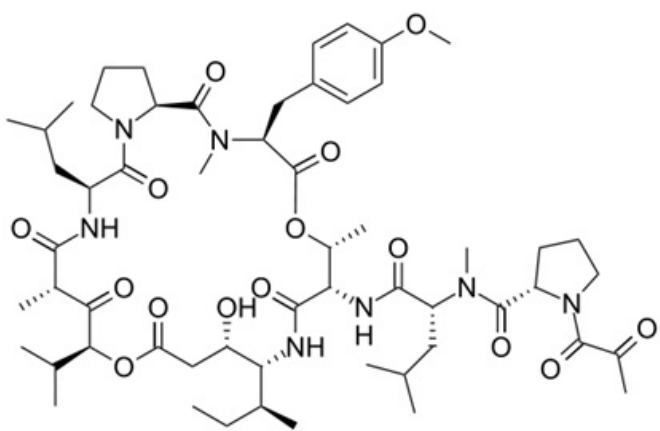

C. Aplidine

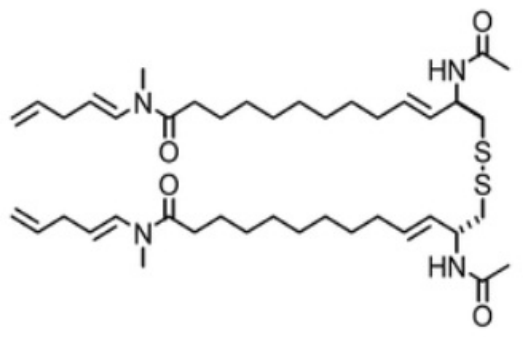

B. Somocystinamide A

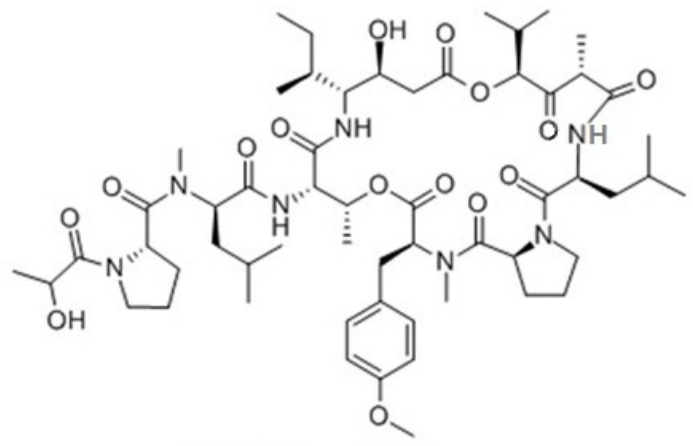

D. Didemnin B

Some other peptides from marine sources, such as Somocystinamide A [31,32] and $C$-phycocyanin (C-PC) [33,34] have been observed to display potent caspases-dependent anti-apoptotic activity in different cancer cells. Somocystinamide A (ScA), a lipopeptide, was isolated from Lyngbya majuscula/Schizothrix sp. assemblage of marine cyanobacteria (Figure 2B) [31]. ScA stimulates apoptosis in a number of tumor cell lines and in angiogenic endothelial cells via both the intrinsic and extrinsic pathways, but the more effective mechanism is the activation of caspase- 8 and its downstream pathways [32]. C-phycocyanin, a tetrapyrrole-protein complex isolated from the cyanobacteria Agmenellum quadruplicatum, Mastigocladus laminosus [33] and Spirulina platensis, could induce the activation of pro-apoptotic gene and down-regulation of anti-apoptotic gene expression, then facilitate the transduction of apoptosis signals that result in the apoptosis of HeLa cells in vitro. Caspases 2, 3, 4, 6, 8, 9, and 10 were activated in C-PC-treated HeLa cells, suggesting that $C$-PC-induced apoptosis was caspases-dependent. $C$-PC treatment of HeLa cells also results in release of cytochrome $\mathrm{c}$ from the mitochondria into the cytosol that was related to apoptosis of $C$-PC-treated HeLa cells [34]. 


\subsection{Peptides that Target the JNK or p38 MAPK Pathway}

Jun $N$-terminal kinases (JNKs) and p38 mitogen-activated protein kinases (MAPKs) play critical roles in the signaling mechanisms that orchestrate cellular responses to various types of cellular stress [35,36]. Unscheduled proliferation is a hallmark of cancer, and the JNK and p38 MAPK pathways regulate cell cycle progression at different points by both transcription-dependent and transcription-independent mechanisms, with profound effects on the development of various cancers. The pro- and anti-apoptotic effects of JNKs seem to be dependent not only on the stimuli, but also on the strength of the signals. Activation of the JNK and p38 MAPK pathways can trigger cytochrome c release and subsequently activate caspases cascades [35].

Aplidine (dehydrodidemnin B, DDB, Aplidin), a cyclic depsipeptide (Figure 2C), was isolated from the Mediterranean tunicate Aplidium albicans. Breast, melanoma and non-small-cell lung cancer appear to be sensitive to low concentrations of Aplidine [37,38]. Aplidine's mechanism of action involves several pathways, including cell cycle arrest, inhibition of protein synthesis. Aplidine induces early oxidative stress and results in a rapid and persistent activation of JNK and p38 MAPK phosphorylation with activation of both kinases occurring very rapid, long before the execution of apoptosis, and full activation within 5-10 min of drug treatment in human HeLa tumor cells. JNK and p38 MAPK activation results in downstream cytochrome c release and activation of caspases-9 and -3 and PARP cleavage, demonstrating the mediation of the mitochondrial apoptotic pathway in this process. Protein kinase $\mathrm{C}$ delta (PKC-d) mediates the cytotoxic effect of Aplidin and that it is concomitantly processed and activated late in the apoptotic process by a caspases mediated mechanism [39]. Aplidin induces apoptosis in MDA-MB-231 breast cancer cells, resulting in sustained activation of the epidermal growth factor receptor (EGFR), the non-receptor protein-tyrosine kinase Src, and the serine/threonine kinases JNK and p38 MAPK. Two mechanisms by which Aplidin activates JNK: rapid activation of Rac1 small GTPase and down regulation of MKP-1 phosphatase. Aplidine, also called plitidepsin in clinical trials, is well-tolerated with minor toxicity in finished Phase I clinical trials [40-42]. Phase II studies are underway [43].

\subsection{Peptides with an Unknown Mechanism of Apoptosis-Inducing Activity}

Some marine peptides are known to induce cell death with apoptotic characteristics, including DNA fragmentation, nucleic shrinking and cell membrane swelling. However, the exact mode of action of cytotoxicity is unclear. Didemnins, originally reported in $1981[44,45]$, are a family of depsipeptides with antitumor, antiviral and immunosuppressive activities primarily isolated from the Caribbean tunicate Trididemnum solidum, but later obtained from other species of the same genus [46,47]. Didemnin B, a branched $N$-methylated cyclic peptolide, originally was isolated from the Trididemnum genus of marine tunicates (Figure 2D). Didemnin B induces death of a variety of transformed cells with apoptotic morphology and DNA fragmentation within the cytosol and the generation of DNA ladders [48], but the exact mechanism for these effects is still obscure [49]. Until today, a lot of Didemnin analogues have been prepared semisynthetically and their biological activities evaluated, including cytotoxicity and antiviral and immunosuppressive properties [46,50]. However, Didemnin B 
continues to be a main focus in clinical investigation, being the first marine natural product currently in clinical trials as an anti-cancer agent [51,52].

Some other peptides from marine sources, such as Sansalvamide A [53,54], Cycloxazoline [55,56] and virenamides $\mathrm{A}-\mathrm{C}$ [57] have been observed to display potent anti-apoptotic activity in different cancer cells but the exact targets by these chemicals have not yet been identified. Sansalvamide A, a cyclic depsipeptide produced by a marine fungus, has demonstrated significant anticancer activity [54]. One of Sansalvamide A analogs caused G (1) phase cell cycle arrest in two human pancreatic cancer cell lines (AsPC-1 and CD18); Sansalvamide A, an inhibitor of topoisomerase I, induces cell death with only some apoptotic characteristics in some cancer cells [53]. Cycloxazoline, a new cyclic hexapeptide is reported from a marine ascidian Lissoclinum bistratum [55]. Accumulation of HL-60 leukemia cells in G2/M and inhibition of cytokinesis was caused by cycloxazoline [56]. Three new linear cytotoxic tripeptides, virenamides $\mathrm{A}-\mathrm{C}$ have been isolated from didemnid ascidian Diplosoma virens [57]. The virenamides showed modest cytotoxicity towards a panel of cultured cells: Virenamide A gave $\mathrm{IC}_{50}$ of $2.5 \mu \mathrm{g} / \mathrm{mL}$ against $\mathrm{P} 388$, and $10 \mu \mathrm{g} / \mathrm{mL}$ against A549, HT29 and CV1 cells, and exhibited topoisomerase II inhibitory activity. Virenamides $\mathrm{B}$ and $\mathrm{C}$ both gave $\mathrm{IC}_{50}$ of $2.5 \mu \mathrm{g} / \mathrm{mL}$ against P388, A549, HT29, and CV1 cells [57].

\section{Peptides that Affect the Tubulin-Microtubule Equilibrium}

Microtubules are intracellular organelles formed from the protein tubulin. These organelles have a number of essential cellular functions including chromosome segregation, the maintenance of cell shape, transport, motility, and organelle distribution. Drugs that affect the tubulin-microtubule equilibrium are effective anticancer drugs [58]. Tubulin binding molecules have generated considerable interest after the successful introduction of the taxanes into clinical oncology and the widespread use of the Vinca alkaloids Vincristine and Vinblastine. These compounds inhibit cell mitosis by binding to the protein tubulin in the mitotic spindle and preventing polymerization into the microtubules (MTs). This mode of action is also shared with other natural agents. Therefore, there is a strong need to design and develop new natural analogs as antimitotic agents to interact with tubulin at sites different from those of Vinca alkaloids and taxanes [59].

Dolastatin 10, a linear pentapeptide containing several unique amino acid subunits (Figure 3A), was derived from the marine mollusk Dolabella auricularia; it is the most potent member of a large class of related peptides [60,61]. Bai et al. reported that Dolastatin 10 inhibited the growth of L1210 murine leukemia cells in culture [62]. Preliminary studies indicated that Dolastatin 10 causes formation of a cold-stable tubulin aggregate at higher drug concentrations. Dolastatin 10 strongly inhibits microtubule assembly, tubulin-dependent GTP hydrolysis [62], and the binding of Vinca alkaloids to tubulin. Dolastatin 10 prevents loss of the stabilizing effects on the colchicine binding activity of tubulin. A tripeptide segment of Dolastatin 10 also effectively inhibits tubulin polymerization and GTP hydrolysis. The tripeptide did not significantly inhibit either vincristine binding or nucleotide exchange [63]. 
Figure 3. Chemical structures of major marine peptides which affect the tubulin-microtubule equilibrium: Dolastatin 10 (A) and Vitilevuamide (B).
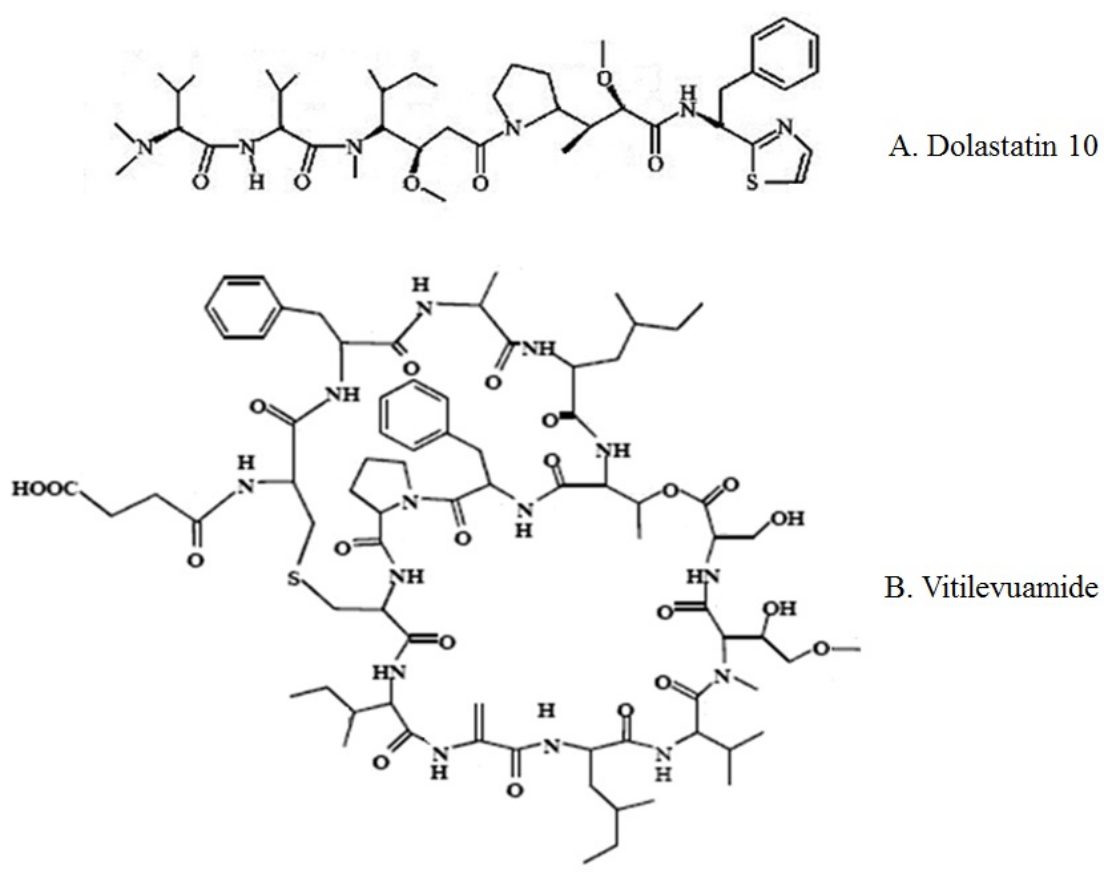

Vitilevuamide, a bicyclic 13 amino acid peptide (Figure 3B), was isolated from two marine ascidians, Didemnum cuculiferum and Polysyncranton lithostrotum. Vitilevuamide was strongly positive in a cell-based screen for inhibitors of tubulin polymerization, displaying activity in vivo against P388 lymphocytic leukemia. Vitilevuamide exhibits non-competitive inhibition of Vinblastine binding to tubulin. Colchicine binding to tubulin was stabilized in the presence of Vitilevuamide. GTP binding was also found to be weakly affected by the presence of Vitilevuamide, suggesting the possibility that Vitilevuamide inhibits tubulin polymerization via an interaction at a unique site [64].

Some other peptides from marine sources, such as Diazonamide A [65,66], Scleritodermin A [67,68], Hemiasterlin [69-72], Desmethoxymajusculamide C (DMMC) [73] and Milnamide D [74] have been observed to display potent inhibition of tubulin polymerization in different cancer cells. Diazonamide A, a complex cytotoxic peptide, was isolated from the marine ascidian Diazona angulata [65]. Diazonamide A and the analog have a unique binding site on tubulin differing from the Vinca alkaloid and Dolastatin 10 binding sites. Diazonamide A and the analog bind weakly to unpolymerized tubulin but strongly to microtubule ends $[65,66]$. Scleritodermin A is a new cyclic peptide isolated from the lithistid sponge Scleritoderma nodosum. Scleritodermin A showed significant in vitro cytotoxicity against human tumor cell lines and inhibited tubulin polymerization [67,68]. Hemiasterlin, a natural tripeptide derived from marine sponges Auletta and Siphonochalina sp., binds to the Vinca-peptide site in tubulin, disrupts normal microtubule dynamics; depolymerize microtubules $[69,70]$. One analogue of Hemiasterlin, HTI-286, inhibits the polymerization of purified tubulin, disrupts microtubule organization in cells. HTI-286 is considered as a potent inhibitor of proliferation and has substantially less interaction with multidrug resistance protein (P-glycoprotein) than currently used antimicrotubule agents [71,72]. Desmethoxymajusculamide C (DMMC), a new cyclic depsipeptide was extracted from the Fijian Cyanobacterium Lyngbya majuscula. DMMC exhibited potent and selective anti-solid tumor 
activity against the HCT-116 human colon carcinoma cell line via disruption of cellular microfilament networks. Linearized DMMC was also evaluated in the biological assays and found to maintain potent actin depolymerization characteristics while displaying solid tumor selectivity equivalent to DMMC in the disk diffusion assay [73].

We purified an antitumor protein from the coelomic fluid of Meretrix meretrix Linnaeus, MML, which exhibited significant cytotoxicity to several cancer cell types, including human hepatoma BEL-7402, human breast cancer MCF-7 and human colon cancer HCT-116 cells. Further studies demonstrated that MML increased cell membrane permenbility and inhibition of tubulin polymerization [75].

\section{Peptides that Inhibit Angiogenesis}

Angiogenesis, the formation of new blood vessels, is a complex multistep process, including the destabilization of established vessel, endothelial cell proliferation, migration and new tube formation. Angiogenesis plays an important role in the growth, invasion and metastasis of most solid tumors. Both tumor growth and metastasis depend on the expansion of host vasculatures into tumors through angiogenesis [76-79]. Vascular endothelial growth factor (VEGF) and its receptor, VEGFR-2 (Flk-1/KDR), play a key role in tumor angiogenesis [80,81]. Tumor growth may be inhibited via blocking the VEGF-VEGFR-2 pathway and downstream intracellular signaling. These pathways include VEGF-induced phosphorylation of extracellular signal-regulated kinase 1/2 (ERK1/2), serine/threonine protein kinase family protein kinase B (Akt), two tumor promoters CXC chemokine Receptor (CXCR4) and Hypoxia inducible factor 1alpha (HIF1 $\alpha$ ) [82,83]. HIF1 $\alpha$, a subunit of HIF1 transcription factor, regulates not only adaptive responses to hypoxia, but also many cellular functions under normoxia. HIF1 $\alpha$ induces VEGF aggregation, actions known to be important for cellular survival and endovascular differentiation $[84,85]$.

Neovastat (AE-941) is a derivative of shark cartilage extract. Rather than being a specific monomolecular compound, AE-941 is a defined standardized liquid extract comprising the $<500 \mathrm{kDa}$ fraction from the cartilage of shark, Squalus acanthias, directly inhibits tumor cell growth and angiogenesis [86,87]. Lee et al. founded that Neovastat was mediated via inhibition of VEGF and HIF2 alpha pathway [88]. Mice treated with Neovastat had significantly reduced inflammatory cell count in BAL fluid. Furthermore, Mice treated with Neovastat showed significantly reduced VEGF and HIF2 alpha expression on lung tissue [88].

We purified a novel linear polypeptide with MW 15500, PG155, with potent anti-angiogenic activity from the cartilage of shark, Prionace glauca. The anti-angiogenic effects of PG155 were evaluated using zebrafish embryos model in vivo. Our study confirmed that PG155 inhibited the growth of SIV of zebrafish embryos. In vitro transwell experiment revealed that the polypeptide inhibited VEGF induced migration and tubulogenesis of human umbilical vein endothelial cells (HUVECs) [89].

Mycothiazole, a mixed polyketide/peptide-derived compound with a central thiazole moiety, inhibited hypoxic HIF1 signaling in tumor cells that correlated with the suppression of HIF1 target gene VEGF expression. Mechanistic studies revealed that mycothiazole selectively suppresses 
mitochondrial respiration at complex I (NADH-ubiquinone oxidoreductase), may serve as a valuable molecular probe for mitochondrial biology and HIF-mediated hypoxic signaling [90].

\section{Peptides with Unknown Mechanism for Their Anti-Tumor Activity}

Although a huge effort has been put on the development of anticancer agents from marine sources, this area is still a virgin field and many fewer peptides have been identified so far compared with the research on the peptides isolated from other natural sources. There are still many other peptides with unknown mechanisms for their induction of cytotoxicity, likely because they involve complicated mechanisms. A lot of peptides were isolated from ascidians, including patellamides [91-94], Styelin D [95], Eusynstyelamide [96], botryllamides A-D (1-4) [97], Lissoclinamides [46,98,99] and Mollamides [100,101], which display potent cytotoxicity, but their exact mechanism have not been well documented. Styelin D, a 32-residue $C$-terminally amidated antimicrobial peptide, isolated from blood cells of the ascidian Styela clava is discovered a cytotoxic peptide, was quite cytotoxic and hemolytic to eukaryotic cells [95]. Lissoclinamides (Lissoclinamides 4 and 5), a cyclic peptide isolated from the aplousobranch ascidian Lissoclinum patella [98], showed relevant antineoplastic as well as other pharmacological properties against human fibroblast and bladder carcinoma cell lines and normal lymphocytes [46]. The most potent is Lissoclinamide 7, containing two thiazoline rings, which rivals Didemnin B in cytotoxicity in vitro [99].

Sponge is another rich resource of peptides, such as Geodiamolides A-G [102,103], Orbiculamide A [104], Koshikamide B [105], Phakellistatins [106-109], Microcionamides A and B [110], Halicylindramides [111], Haligramides [112], Hemiasterlin [113], Milnamide A [114], Corticiamide A [115], Theopapuamide [116], Taumycins A [117], Koshikamide A1 [118], Koshikamide A2 [119] and Efrapeptin G [120] have been observed to display potent cytotoxicity in different cancer cells but the exact targets by these chemicals have not yet been identified. Geodiamolides A-G initially isolated from the Caribbean sponge Geodia sp. are a group of cytotoxic peptides in which there is three amino acids forming a cyclic peptide with a common polyketide unit [102,103]. Orbiculamide A, acyclic peptide from a marine sponge Theonella sp., is cytotoxic against P388 murine leukemia cells $\left(\mathrm{ED}_{50}=0.34 \mu \mathrm{g} / \mathrm{mL}\right)$, but also against different melanoma cell lines [104]. Koshikamide B, a cytotoxic peptide lactone from a marine sponge Theonella sp., is a 17-residue peptide lactone composed of six proteinogenic amino acids, two D-isomers of proteinogenic amino acids, seven $\mathrm{N}$-methylated amino acids, and two unusual amino acid residues. Koshikamide B exhibits cytotoxicity against P388 murine leukemia cells and the human colon tumor (HCT-116) cell line [105]. Phakellistatins, isolated from two Indo-Pacific sponges, Phakellia costata and Stylotella aurantium, are a group of proline rich cyclic heptapeptides; Phakellistatin 1, showed potent activity against P388 murine leukemia cells and other different melanoma cell lines [106]. Microcionamides A and B, new linear peptides cyclized via a cysteine moiety and isolated from the Philippine Sponge Clathria (Thalysias) abietina, exhibited significant cytotoxicity against the human breast tumor cells lines MCF-7 and SKBR-3 and displayed inhibitory activity against Mycobacterium tuberculosis H37Ra [110]. Similarly, several other marine anticancer peptides, including Keenamide A [121], Kulokekahilide-1 [122], Kulokekahilide-2 [123] and Scopularide A and B [124], also elicit antitumor activity via unknown mechanisms. Keenamide A, a new cytotoxic cyclic hexapeptide, was isolated 
from the notaspidean mollusk Pleurobranchus forskalii. Keenamide A exhibited significant activity against the P388, A549, MEL-20, and HT-29 tumor cell lines [121].

Some other antitumor peptides including Symplocamide A [125,126], Apratoxin D [127,128] and Mitsoamide [129] have been isolated recently from Cyanobacteria. Symplocamide A is a newly discovered 3-amino-6-hydroxy-2-piperidone (Ahp) cyclodepsipeptide, isolated from a marine cyanobacteria Symploca sp. in Papua New Guinea [126]. Symplocamide A is an extremely potent cytotoxin, with $\mathrm{IC}_{50}$ in nanomole level for $\mathrm{H} 460$ lung cancer and neuro-2A neuroblastoma cell lines [125]. Apratoxin D was extracted from marine cyanobacteria Lyngbya majuscula and Lyngbya sordida. Apratoxin D showed potent in vitro cytotoxicity against $\mathrm{H}-460$ human lung cancer cells with an $\mathrm{IC}_{50}$ value of $2.6 \mathrm{nM}$ [127]. Recently, a new cytotoxic and linear peptide was isolated from the marine cyanobacteria Geitlerinema sp. [129]. Additionally, two novel cyclodepsipeptides, Scopularides A and B were found in the fungus Scopulariopsis brevicaulis and activity of Scopularides against several tumor cell lines was significant at $10 \mu \mathrm{g} / \mathrm{mL}$ [124]. However, the exact mechanisms by these peptides have not yet been identified.

\section{Conclusions}

The discussed marine peptides and their mode actions are summarized in Table 1. However, a lot of marine peptides display antitumor activity via multiple targets. Dolastatin 10 not only inhibits microtubule assembly, but also induces apoptosis associating with a decrease in Bcl-2 level and an increase in p53 expression in the lymphoma cell line [130]. Aplidine's mechanism of action involves several pathways, including cell cycle arrest, inhibition of protein synthesis and anti-angiogenic activity [131].

Table 1. A summary of marine peptides and their mode of actions.

\begin{tabular}{|c|c|c|c|}
\hline Name of peptides & Sources & Class/types & Mode of action and references \\
\hline $\begin{array}{c}\text { Jaspamide } \\
\text { (Jasplakinolide) }\end{array}$ & Marine sponge, Jaspis johnstoni & $\begin{array}{c}\text { Cyclic } \\
\text { depsipeptide }\end{array}$ & $\begin{array}{l}\text { Caspase- } 3 \text { activation, decreasing in } \\
\text { Bcl-2 protein expression [28-30] }\end{array}$ \\
\hline $\begin{array}{c}\text { Somocystinamide A } \\
(\mathrm{ScA})\end{array}$ & $\begin{array}{l}\text { Lyngbya majuscula/ Schizothrix sp. } \\
\text { assemblage of marine cyanobacteria }\end{array}$ & Lipopeptide & Caspase- 8 activation $[31,32]$ \\
\hline$C$-phycocyanin $(C$-PC) & $\begin{array}{c}\text { Cyanobacteria Agmenellum } \\
\text { quadruplicatum, Mastigocladus } \\
\text { laminosus, Spirulina platensis }\end{array}$ & $\begin{array}{c}\text { Tetrapyrrole- } \\
\text { protein complex }\end{array}$ & Caspases-dependent apoptosis [34] \\
\hline $\begin{array}{c}\text { Aplidine } \\
\text { (dehydrodidemnin B, } \\
\text { DDB, Aplidin) }\end{array}$ & Tunicate, Aplidium albicans & $\begin{array}{c}\text { Cyclic } \\
\text { depsipeptide }\end{array}$ & $\begin{array}{c}\text { JNK and p38 MAPK } \\
\text { phosphorylation activation [37-39] }\end{array}$ \\
\hline Didemnin B & Tunicate, Trididemnum solidum & $\begin{array}{c}\text { Cyclic } \\
\text { depsipeptide }\end{array}$ & Apoptosis, but unclear [44-49] \\
\hline Sansalvamide A & Marine fungus & $\begin{array}{c}\text { Cyclic } \\
\text { depsipeptide }\end{array}$ & Apoptosis, but unclear $[53,54]$ \\
\hline Cycloxazoline & $\begin{array}{c}\text { Marine ascidian, } \\
\text { Lissoclinum bistratum }\end{array}$ & $\begin{array}{c}\text { Cyclic } \\
\text { depsipeptide }\end{array}$ & Apoptosis, but unclear $[55,56]$ \\
\hline Virenamides $\mathrm{A}-\mathrm{C}$ & $\begin{array}{l}\text { Didemnid ascidian, } \\
\text { Diplosoma virens }\end{array}$ & Linear tripeptides & Apoptosis, but unclear [57] \\
\hline
\end{tabular}


Table 1. Cont.

\begin{tabular}{|c|c|c|c|}
\hline Name of peptides & Sources & Class/types & Mode of action and references \\
\hline Dolastatin 10 & $\begin{array}{c}\text { Marine mollusk, } \\
\text { Dolabella auricularia }\end{array}$ & Linear peptide & $\begin{array}{l}\text { Microtubule assembly } \\
\text { Inhibition }[60,62]\end{array}$ \\
\hline Vitilevuamide & $\begin{array}{c}\text { Marine ascidians, } \\
\text { Didemnum cuculiferum and } \\
\text { Polysyncranton lithostrotum }\end{array}$ & Bicyclic peptide & $\begin{array}{l}\text { Tubulin polymerization } \\
\text { inhibition [64] }\end{array}$ \\
\hline Diazonamide & Marine ascidian, Diazona angulata & Macrocyclic peptide & $\begin{array}{l}\text { Tubulin polymerization } \\
\text { inhibition }[65,66]\end{array}$ \\
\hline Scleritodermin A & $\begin{array}{c}\text { Lithistid sponge, } \text { Scleritoderma } \\
\text { nodosum }\end{array}$ & Cyclic peptide & $\begin{array}{c}\text { Tubulin polymerization } \\
\text { inhibition }[67,68]\end{array}$ \\
\hline Hemiasterlin & $\begin{array}{l}\text { Marine sponges, Auletta sp. and } \\
\text { Siphonochalina sp. }\end{array}$ & Tripeptide & $\begin{array}{l}\text { Tubulin polymerization } \\
\text { inhibition [70-72] }\end{array}$ \\
\hline DMMC & Cyanobacterium Lyngbya majuscula & Cyclic depsipeptide & $\begin{array}{c}\text { Tubulin polymerization } \\
\text { inhibition [73] }\end{array}$ \\
\hline MML & Coelomic fluid, Meretrix meretrix & Protein & $\begin{array}{l}\text { Tubulin polymerization } \\
\text { inhibition [75] }\end{array}$ \\
\hline Neovastat (AE-941) & Shark cartilage, Squalus acanthias & Extract $<500 \mathrm{kDa}$ & $\begin{array}{l}\text { VEGF and HIF2 alpha pathway } \\
\text { inhibition [86-88] }\end{array}$ \\
\hline PG155 & Shark cartilage, Prionace glauca & Polypeptide & $\begin{array}{l}\text { VEGF induced angiogenesis } \\
\text { inhibition [89] }\end{array}$ \\
\hline Styelin D & Ascidian, Styela clava & $\begin{array}{c}C \text {-terminally } \\
\text { amidated peptide }\end{array}$ & Unknown [95] \\
\hline Lissoclinamides & $\begin{array}{l}\text { Aplousobranch ascidian, Lissoclinum } \\
\text { patella }\end{array}$ & Cyclic peptide & Unknown $[46,98,99]$ \\
\hline Geodiamolides A-G & Caribbean sponge, Geodia sp. & Cyclic peptide & Unknown $[102,103]$ \\
\hline Orbiculamide A & Marine sponge, Theonella sp. & Cyclic peptide & Unknown [104] \\
\hline Koshikamide B & Marine sponge, Theonella sp. & Peptide lactone & Unknown [105] \\
\hline Phakellistatins & Marine sponges & Cyclic heptapeptides & Unknown [106-109] \\
\hline $\begin{array}{l}\text { Microcionamides A } \\
\text { and B } \\
\end{array}$ & $\begin{array}{l}\text { Philippine Sponge, Clathria } \\
\text { (Thalysias) abietina }\end{array}$ & Linear peptides & Unknown [110] \\
\hline Keenamide A & $\begin{array}{l}\text { Notaspidean mollusk, } \\
\text { Pleurobranchus forskalii }\end{array}$ & Cyclic hexapeptide & Unknown [121] \\
\hline Scopularides A and B & Fungus Scopulariopsis brevicaulis & Cyclodepsipeptide & Unknown [124] \\
\hline Symplocamide A & Marine cyanobacteria Symploca sp. & Cyclodepsipeptide & Unknown $[125,126]$ \\
\hline Apratoxin D & $\begin{array}{l}\text { Marine cyanobacteria Lyngbya } \\
\text { majuscula and Lyngbya sordida }\end{array}$ & Macrocycle peptide & Unknown $[127,128]$ \\
\hline Mitsoamide & $\begin{array}{c}\text { Marine cyanobacteria } \\
\text { Geitlerinema } \mathrm{sp} .\end{array}$ & Linear peptide & Unknown [129] \\
\hline
\end{tabular}

Peptide compounds reviewed here are obtained from very different marine organisms with different mechanism on their antitumor activity. Because of the peculiarities of the life in the sea, many of these molecules can be found only in a single source For example, Jaspamide (Jasplakinolide) is only found in marine sponge Jaspis species [28-30], and Trididemnum genus of marine tunicate is the only source for Didemnin B [44-49]. Although the underling mechanism of source specificity of the marine 
peptides is unclear, it is conceivable that the special environment of marine offers the diversity of marine natural products. It is also possible that the organisms, which may contain the peptides, have not been found since the study of marine peptides is still in its infancy. Compared with the peptides found from other sources, there is more diversity on the style/classes of marine peptides; more cyclic peptides or depsipeptide were found in marine organism. These marine peptides seem to be very useful and promising for biomedical research. There is no doubt that the diversity of marine peptides in its structure and mode of action provide a rich source for the design of very specific and potent new pharmaceuticals for a wide variety of diseases.

\section{Acknowledgments}

This work was supported by the National Natural Science Foundation of China (No. 30801453 and 81072065) and National Innovative Drug Development Programs of China (No. 2009ZX09102-240 and 2009ZX09103-661).

\section{References}

1. de Vries, D.J.; Beart, P.M. Fishing for drugs from the sea: Status and strategies. Trends Pharmacol. Sci. 1995, 16, 275-279.

2. Reed, J.C. Mechanisms of apoptosis. Am. J. Pathol. 2000, 157, 1415-1430.

3. Danial, N.N.; Korsmeyer, S.J. Cell death: Critical control points. Cell 2004, 116, 205-219.

4. Thompson, C.B. Apoptosis in the pathogenesis and treatment of disease. Science 1995, 267, 1456-1462.

5. Rowinsky, E.K. Targeted induction of apoptosis in cancer management: The emerging role of tumor necrosis factor-related apoptosis-inducing ligand receptor activating agents. J. Clin. Oncol. 2005, 23, 9394-9407.

6. Call, J.A.; Eckhardt, S.G.; Camidge, D.R. Targeted manipulation of apoptosis in cancer treatment. Lancet Oncol. 2008, 9, 1002-1011.

7. Iannolo, G.; Conticello, C.; Memeo, L.; de Maria, R. Apoptosis in normal and cancer stem cells. Crit. Rev. Oncol. Hematol. 2008, 66, 42-51.

8. Burz, C.; Berindan-Neagoe, I.; Balacescu, O.; Irimie, A. Apoptosis in cancer: Key molecular signaling pathways and therapy targets. Acta Oncol. 2009, 48, 811-821.

9. Fulda, S.; Pervaiz, S. Apoptosis signaling in cancer stem cells. Int. J. Biochem. Cell Biol. 2009, $42,31-38$.

10. Ghobrial, I.M.; Witzig, T.E.; Adjei, A.A. Targeting apoptosis pathways in cancer therapy. $C A$ Cancer J. Clin. 2005, 55, 178-194.

11. Eberle, J.; Fecker, L.F.; Forschner, T.; Ulrich, C.; Rowert-Huber, J.; Stockfleth, E. Apoptosis pathways as promising targets for skin cancer therapy. Br. J. Dermatol. 2007, 156S, 18-24.

12. Ziegler, D.S.; Kung, A.L. Therapeutic targeting of apoptosis pathways in cancer. Curr. Opin. Oncol. 2008, 20, 97-103.

13. Cheng, L.; Wang, X.; Zhang, J.; Zhang, S.B.; Zheng, S.Q.; Zheng, J. Targeting apoptosis signaling pathways in cancer therapy. Zhonghua Bing Li Xue Za Zhi 2009, 38, 639-642. 
14. Lin, X.; Liu, M.; Hu, C.; Liao, D.J. Targeting cellular proapoptotic molecules for developing anticancer agents from marine sources. Curr. Drug Targets 2010, 11, 708-715.

15. von Schwarzenberg, K.; Vollmar, A.M. Targeting apoptosis pathways by natural compounds in cancer: Marine compounds as lead structures and chemical tools for cancer therapy. Cancer Lett. 2010, doi:10.1016/j.canlet.2010.07.004.

16. Abe, K.; Kurakin, A.; Mohseni-Maybodi, M.; Kay, B.; Khosravi-Far, R. The complexity of TNF-related apoptosis-inducing ligand. Ann. N. Y. Acad. Sci. 2000, 926, 52-63.

17. Ozoren, N.; El-Deiry, W.S. Cell surface Death Receptor signaling in normal and cancer cells. Semin. Cancer Biol. 2003, 13, 135-147.

18. Peter, M.E.; Krammer, P.H. The CD95(APO-1/Fas) DISC and beyond. Cell Death Differ. 2003, $10,26-35$.

19. Thorburn, A. Death receptor-induced cell killing. Cell Signal 2004, 16, 139-144.

20. Kroemer, G. Mitochondrial control of apoptosis: An introduction. Biochem. Biophys. Res. Commun. 2003, 304, 433-435.

21. Gupta, S.; Kass, G.E.; Szegezdi, E.; Joseph, B. The mitochondrial death pathway: A promising therapeutic target in diseases. J. Cell. Mol. Med. 2009, 13, 1004-1033.

22. Yip, K.W.; Reed, J.C. Bcl-2 family proteins and cancer. Oncogene 2008, 27, 6398-6406.

23. Okun, I.; Balakin, K.V.; Tkachenko, S.E.; Ivachtchenko, A.V. Caspase activity modulators as anticancer agents. Anticancer Agents Med. Chem. 2008, 8, 322-341.

24. Ghavami, S.; Hashemi, M.; Ande, S.R.; Yeganeh, B.; Xiao, W.; Eshraghi, M.; Bus, C.J.; Kadkhoda, K.; Wiechec, E.; Halayko, A.J.; Los, M. Apoptosis and cancer: Mutations within caspase genes. J. Med. Genet. 2009, 46, 497-510.

25. Park, H.J.; Kim, B.C.; Kim, S.J.; Choi, K.S. Role of MAP kinases and their cross-talk in TGF-beta1-induced apoptosis in $\mathrm{FaO}$ rat hepatoma cell line. Hepatology 2002, 35, 1360-1371.

26. Kang, M.H.; Reynolds, C.P. Bcl-2 inhibitors: Targeting mitochondrial apoptotic pathways in cancer therapy. Clin. Cancer Res. 2009, 15, 1126-1132.

27. Wong, W.W.; Puthalakath, H. Bcl-2 family proteins: The sentinels of the mitochondrial apoptosis pathway. IUBMB Life 2008, 60, 390-397.

28. Braekman, J.C.; Daloze, D.; Moussiaux, B.; Riccio, R. Jaspamide from the marine sponge Jaspis johnstoni. J. Nat. Prod. 1987, 50, 994-995.

29. Odaka, C.; Sanders, M.L.; Crews, P. Jasplakinolide induces apoptosis in various transformed cell lines by a caspase-3-like protease-dependent pathway. Clin. Diagn. Lab. Immunol. 2000, 7, 947-952.

30. Cioca, D.P.; Kitano, K. Induction of apoptosis and CD10/neutral endopeptidase expression by jaspamide in HL-60 line cells. Cell. Mol. Life Sci. 2002, 59, 1377-1387.

31. Nogle, L.M.; Gerwick, W.H. Somocystinamide A, a novel cytotoxic disulfide dimer from a Fijian marine cyanobacterial mixed assemblage. Org. Lett. 2002, 4, 1095-1098.

32. Wrasidlo, W.; Mielgo, A.; Torres, V.A.; Barbero, S.; Stoletov, K.; Suyama, T.L.; Klemke, R.L.; Gerwick, W.H.; Carson, D.A.; Stupack, D.G. The marine lipopeptide somocystinamide A triggers apoptosis via caspase 8. Proc. Natl. Acad. Sci. USA 2008, 105, 2313-2318. 
33. Schirmer, T.; Huber, R.; Schneider, M.; Bode, W.; Miller, M.; Hackert, M.L. Crystal structure analysis and refinement at $2.5 \AA$ of hexameric $C$-phycocyanin from the cyanobacterium Agmenellum quadruplicatum: The molecular model and its implications for light-harvesting. J. Mol. Biol. 1986, 188, 651-676.

34. Li, B.; Gao, M.H.; Zhang, X.C.; Chu, X.M. Molecular immune mechanism of $C$-phycocyanin from Spirulina platensis induces apoptosis in HeLa cells in vitro. Biotechnol. Appl. Biochem. 2006, 43, 155-164.

35. Dhanasekaran, D.N.; Reddy, E.P. JNK signaling in apoptosis. Oncogene 2008, 27, 6245-6251.

36. Wagner, E.F.; Nebreda, A.R. Signal integration by JNK and p38 MAPK pathways in cancer development. Nat. Rev. Cancer 2009, 9, 537-549.

37. Depenbrock, H.; Peter, R.; Faircloth, G.T.; Manzanares, I.; Jimeno, J.; Hanauske, A.R. In vitro activity of aplidine, a new marine-derived anti-cancer compound, on freshly explanted clonogenic human tumour cells and haematopoietic precursor cells. Br. J. Cancer 1998, 78, 739-744.

38. Urdiales, J.L.; Morata, P.; de Castro, I.N.; Sánchez-Jiménez, F. Antiproliferative effect of dehydrodidemnin B (DDB), a depsipeptide isolated from Mediterranean tunicates. Cancer Lett. 1996, 102, 31-37.

39. Garcia-Fernandez, L.F.; Losada, A.; Alcaide, V.; Alvarez, A.M.; Cuadrado, A.; Gonzalez, L.; Nakayama, K.; Nakayama, K.I.; Fernandez-Sousa, J.M.; Munoz, A.; et al. Aplidin induces the mitochondrial apoptotic pathway via oxidative stress-mediated JNK and p38 activation and protein kinase C delta. Oncogene 2002, 21, 7533-7544.

40. Rinehart, K.L. Antitumor compounds from tunicates. Med. Res. Rev. 2000, 20, 1-27.

41. Faivre, S.; Chieze, S.; Delbaldo, C.; Ady-Vago, N.; Guzman, C.; Lopez-Lazaro, L.; Lozahic, S.; Jimeno, J.; Pico, F.; Armand, J.P.; et al. Phase I and pharmacokinetic study of aplidine, a new marine cyclodepsipeptide in patients with advanced malignancies. J. Clin. Oncol. 2005, 23, 7871-7880.

42. Maroun, J.A.; Belanger, K.; Seymour, L.; Matthews, S.; Roach, J.; Dionne, J.; Soulieres, D.; Stewart, D.; Goel, R.; Charpentier, D.; et al. Phase I study of Aplidine in a dailyx 5 one-hour infusion every 3 weeks in patients with solid tumors refractory to standard therapy. A National Cancer Institute of Canada Clinical Trials Group study: NCIC CTG IND 115. Ann. Oncol. 2006, 17, 1371-1378.

43. Nalda-Molina, R.; Valenzuela, B.; Ramon-Lopez, A.; Miguel-Lillo, B.; Soto-Matos, A.; Perez-Ruixo, J.J. Population pharmacokinetics meta-analysis of plitidepsin (Aplidin) in cancer subjects. Cancer Chemother. Pharmacol. 2009, 64, 97-108.

44. Rinehart, K.L.; Gloer, J.B.; Cook, J.C.; Mizsak, S.A.; Scahill, T.A. Structures of the didemnins, antiviral and cytotoxic depsipeptides from a Caribbean tunicate. J. Am. Chem. Soc. 1981, 103, 1857-1859.

45. Rinehart, K., Jr.; Gloer, J.; Hughes, R., Jr.; Renis, H.; McGovren, J.; Swynenberg, E.; Stringfellow, D.; Kuentzel, S.; Li, L. Didemnins: Antiviral and antitumor depsipeptides from a caribbean tunicate. Science 1981, 212, 933-935.

46. Schmitz, F.; Bowden, B.; Toth, S. Antitumor and cytotoxic compounds from marine organisms. Mar. Biotechnol. 1993, 1, 197-308. 
47. Blunden, G. Biologically active compounds from marine organisms. Phytother. Res. 2001, 15, 89-94.

48. Grubb, D.R.; Wolvetang, E.J.; Lawen, A. Didemnin B induces cell death by apoptosis: The fastest induction of apoptosis ever described. Biochem. Biophys. Res. Commun. 1995, 215, 1130-1136.

49. Johnson, K.L.; Lawen, A. Rapamycin inhibits didemnin B-induced apoptosis in human HL-60 cells: Evidence for the possible involvement of FK506-binding protein 25. Immunol. Cell Biol. 1999, 77, 242-248.

50. Vervoort, H.; Fenical, W.; Epifanio, R.A. Tamandarins A and B: New cytotoxic depsipeptides from a Brazilian ascidian of the family Didemnidae. J. Org. Chem. 2000, 65, 782-792.

51. Chun, H.; Davies, B.; Hoth, D.; Suffness, M.; Plowman, J.; Flora, K.; Grieshaber, C.; Leyland-Jones, B. Didemnin B. Investig. New Drugs 1986, 4, 279-284.

52. Rinehart, K.L.; Holt, T.G.; Fregeau, N.L.; Keifer, P.A.; Wilson, G.R.; Perun, T.J.; Sakai, R.; Thompson, A.G.; Stroh, J.G.; Shield, L.S.; Seigler, D.S.; Li, L.H.; Martin, D.G.; Grimmelikhuijzen, C.J.P.; Gäde, G. Bioactive Compounds from Aquatic and Terrestrial Sources. J. Nat. Prod. 1990, 53, 771-792.

53. Hwang, Y.; Rowley, D.; Rhodes, D.; Gertsch, J.; Fenical, W.; Bushman, F. Mechanism of inhibition of a poxvirus topoisomerase by the marine natural product sansalvamide A. Mol. Pharmacol. 1999, 55, 1049-1053.

54. Pan, P.S.; Vasko, R.C.; Lapera, S.A.; Johnson, V.A.; Sellers, R.P.; Lin, C.C.; Pan, C.M.; Davis, M.R.; Ardi, V.C.; McAlpine, S.R. A comprehensive study of Sansalvamide A derivatives: The structure-activity relationships of 78 derivatives in two pancreatic cancer cell lines. Bioorg. Med. Chem. 2009, 17, 5806-5825.

55. Hambley, T.W.; Hawkins, C.J.; Lavin, M.F.; van den Brenk, A.; Watters, D.J. Cycloxazoline: A cytotoxic cyclic hexapeptide from the ascidian lissoclinum bistratum. Tetrahedron 1992, 48, 341-348.

56. Watters, D.J.; Beamish, H.J.; Marshall, K.A.; Gardiner, R.A.; Seymour, G.J.; Lavin, M.F. Accumulation of HL-60 leukemia cells in G2/M and inhibition of cytokinesis caused by two marine compounds, bistratene A and cycloxazoline. Cancer Chemother. Pharmacol. 1994, 33, 399-409.

57. Carroll, A.R.; Feng, Y.; Bowden, B.F.; Coll, J.C. Studies of Australian Ascidians. 5. Virenamides A-C, New Cytotoxic Linear Peptides from the Colonial Didemnid Ascidian Diplosoma virens. J. Org. Chem. 1996, 61, 4059-4061.

58. Hadfield, J.A.; Ducki, S.; Hirst, N.; McGown, A.T. Tubulin and microtubules as targets for anticancer drugs. Prog. Cell Cycle Res. 2003, 5, 309-325.

59. Islam, M.N.; Iskander, M.N. Microtubulin binding sites as target for developing anticancer agents. Mini Rev. Med. Chem. 2004, 4, 1077-1104.

60. Pettit, G.R.; Kamano, Y.; Fujii, Y.; Herald, C.L.; Inoue, M.; Brown, P.; Gust, D.; Kitahara, K.; Schmidt, J.M.; Doubek, D.L.; Michel, C. Marine animal biosynthetic constituents for cancer chemotherapy. J. Nat. Prod. 1981, 44, 482-485.

61. Luesch, H.; Moore, R.E.; Paul, V.J.; Mooberry, S.L.; Corbett, T.H. Isolation of Dolastatin 10 from the Marine Cyanobacterium Symploca Species VP642 and Total Stereochemistry and Biological Evaluation of Its Analogue Symplostatin 1. J. Nat. Prod. 2001, 64, 907-910. 
62. Bai, R.; Pettit, G.R.; Hamel, E. Dolastatin 10, a powerful cytostatic peptide derived from a marine animal. Inhibition of tubulin polymerization mediated through the Vinca alkaloid binding domain. Biochem. Pharmacol. 1990, 39, 1941-1949.

63. Bai, R.L.; Pettit, G.R.; Hamel, E. Binding of dolastatin 10 to tubulin at a distinct site for peptide antimitotic agents near the exchangeable nucleotide and Vinca alkaloid sites. J. Biol. Chem. 1990, 265, 17141-17149.

64. Edler, M.C.; Fernandez, A.M.; Lassota, P.; Ireland, C.M.; Barrows, L.R. Inhibition of tubulin polymerization by vitilevuamide, a bicyclic marine peptide, at a site distinct from colchicine, the Vinca alkaloids, and dolastatin 10. Biochem. Pharmacol. 2002, 63, 707-715.

65. Cruz-Monserrate, Z.; Vervoort, H.C.; Bai, R.; Newman, D.J.; Howell, S.B.; Los, G.; Mullaney, J.T.; Williams, M.D.; Pettit, G.R.; Fenical, W.; Hamel, E. Diazonamide A and a synthetic structural analog: Disruptive effects on mitosis and cellular microtubules and analysis of their interactions with tubulin. Mol. Pharmacol. 2003, 63, 1273-1280.

66. Lachia, M.; Moody, C.J. The synthetic challenge of diazonamide A, a macrocyclic indole bis-oxazole marine natural product. Nat. Prod. Rep. 2008, 25, 227-253.

67. Schmidt, E.W.; Raventos-Suarez, C.; Bifano, M.; Menendez, A.T.; Fairchild, C.R.; Faulkner, D.J. Scleritodermin A, a cytotoxic cyclic peptide from the lithistid sponge Scleritoderma nodosum. J. Nat. Prod. 2004, 67, 475-478.

68. Liu, S.; Cui, Y.M.; Nan, F.J. Total synthesis of the originally proposed and revised structures of scleritodermin A. Org. Lett. 2008, 10, 3765-3768.

69. Anderson, H.J.; Coleman, J.E.; Andersen, R.J.; Roberge, M. Cytotoxic peptides hemiasterlin, hemiasterlin A and hemiasterlin B induce mitotic arrest and abnormal spindle formation. Cancer Chemother. Pharmacol. 1997, 39, 223-226.

70. Gamble, W.R.; Durso, N.A.; Fuller, R.W.; Westergaard, C.K.; Johnson, T.R.; Sackett, D.L.; Hamel, E.; Cardellina Ii, J.H.; Boyd, M.R. Cytotoxic and tubulin-interactive hemiasterlins from Auletta sp. and Siphonochalina spp. sponges. Bioorg. Med. Chem. 1999, 7, 1611-1165.

71. Loganzo, F.; Discafani, C.M.; Annable, T.; Beyer, C.; Musto, S.; Hari, M.; Tan, X.; Hardy, C.; Hernandez, R.; Baxter, M.; et al. HTI-286, a synthetic analogue of the tripeptide hemiasterlin, is a potent antimicrotubule agent that circumvents P-glycoprotein-mediated resistance in vitro and in vivo. Cancer Res. 2003, 63, 1838-1845.

72. Yamashita, A.; Norton, E.B.; Kaplan, J.A.; Niu, C.; Loganzo, F.; Hernandez, R.; Beyer, C.F.; Annable, T.; Musto, S.; Discafani, C.; et al. Synthesis and activity of novel analogs of hemiasterlin as inhibitors of tubulin polymerization: Modification of the A segment. Bioorg. Med. Chem. Lett. 2004, 14, 5317-5322.

73. Simmons, T.L.; Nogle, L.M.; Media, J.; Valeriote, F.A.; Mooberry, S.L.; Gerwick, W.H. Desmethoxymajusculamide C, a cyanobacterial depsipeptide with potent cytotoxicity in both cyclic and ring-opened forms. J. Nat. Prod. 2009, 72, 1011-1016.

74. Chevallier, C.; Richardson, A.D.; Edler, M.C.; Hamel, E.; Harper, M.K.; Ireland, C.M. A new cytotoxic and tubulin-interactive milnamide derivative from a marine sponge Cymbastela sp. Org. Lett. 2003, 5, 3737-3739. 
75. Ning, X.; Zhao, J.; Zhang, Y.; Cao, S.; Liu, M.; Ling, P.; Lin, X. A novel anti-tumor protein extracted from Meretrix meretrix Linnaeus induces cell death by increasing cell permeability and inhibiting tubulin polymerization. Int. J. Oncol. 2009, 35, 805-812.

76. Folkman, J. The role of angiogenesis in tumor growth. Semin. Cancer Biol. 1992, 3, 65-71.

77. Folkman, J. Angiogenesis in cancer, vascular, rheumatoid and other disease. Nat. Med. 1995, 1, 27-31.

78. Bouck, N.; Stellmach, V.; Hsu, S.C. How tumors become angiogenic. Adv. Cancer Res. 1996, 69, 135-174.

79. Folkman, J. Angiogenesis and angiogenesis inhibition: An overview. EXS 1997, 79, 1-8.

80. Ferrara, N. VEGF: An update on biological and therapeutic aspects. Curr. Opin. Biotechnol. 2000, 11, 617-624.

81. Ferrara, N.; Gerber, H.P.; LeCouter, J. The biology of VEGF and its receptors. Nat. Med. 2003, 9, 669-676.

82. Nakamura, S.; Chikaraishi, Y.; Tsuruma, K.; Shimazawa, M.; Hara, H. Ruboxistaurin, a PKCbeta inhibitor, inhibits retinal neovascularization via suppression of phosphorylation of ERK1/2 and Akt. Exp. Eye Res. 2009, 90, 137-145.

83. Ushio-Fukai, M. Redox signaling in angiogenesis: Role of NADPH oxidase. Cardiovasc. Res. 2006, 71, 226-235.

84. Chiavarina, B.; Whitaker-Menezes, D.; Migneco, G.; Martinez-Outschoorn, U.E.; Pavlides, S.; Howell, A.; Tanowitz, H.B.; Casimiro, M.C.; Wang, C.; Pestell, R.G.; et al. HIF1-alpha functions as a tumor promoter in cancer associated fibroblasts, and as a tumor suppressor in breast cancer cells: Autophagy drives compartment-specific oncogenesis. Cell Cycle 2010, 9, 3534-3551.

85. Fukushima, K.; Murata, M.; Hachisuga, M.; Tsukimori, K.; Seki, H.; Takeda, S.; Asanoma, K.; Wake, N. Hypoxia inducible factor 1 alpha regulates matrigel-induced endovascular differentiation under normoxia in a human extravillous trophoblast cell line. Placenta 2008, 29, 324-331.

86. Lee, A.; Langer, R. Shark cartilage contains inhibitors of tumor angiogenesis. Science 1983, 221, $1185-1187$.

87. Dupont, E.; Brazeau, P.; Juneau, C. Extracts of shark cartilage having an anti-angiogenic activity and an effect on tumor regression: Process of making thereof. U.S. Patents 5,985,839, 16 November 1999.

88. Lee, S.Y.; Chung, S.M. Neovastat (AE-941) inhibits the airway inflammation via VEGF and HIF-2 alpha suppression. Vasc. Pharmacol. 2007, 47, 313-318.

89. Zheng, L.; Ling, P.; Wang, Z.; Niu, R.; Hu, C.; Zhang, T.; Lin, X. A novel polypeptide from shark cartilage with potent anti-angiogenic activity. Cancer Biol. Ther. 2007, 6, 775-780.

90. Morgan, J.B.; Mahdi, F.; Liu, Y.; Coothankandaswamy, V.; Jekabsons, M.B.; Johnson, T.A.; Sashidhara, K.V.; Crews, P.; Nagle, D.G.; Zhou, Y.D. The marine sponge metabolite mycothiazole: A novel prototype mitochondrial complex I inhibitor. Bioorg. Med. Chem. 2010, 18, 5988-5994.

91. McDonald, L.A.; Ireland, C.M. Patellamide E: A new cyclic peptide from the ascidian Lissoclinum patella. J. Nat. Prod. 1992, 55, 376-379. 
92. Rashid, M.A.; Gustafson, K.R.; Cardellina, J.H., II; Boyd, M.R. Patellamide F, A new cytotoxic cyclic peptide from the colonial ascidian Lissoclinum patella. J. Nat. Prod. 1995, 58, 594-597.

93. Fu, X.; Do, T.; Schmitz, F.J.; Andrusevich, V.; Engel, M.H. New cyclic peptides from the ascidian Lissoclinum patella. J. Nat. Prod. 1998, 61, 1547-1551.

94. Fu, X.; Su, J.; Zeng, L. Prepatellamide A, a new cyclic peptide from the ascidian Lissoclinum patella. Sci. China Ser. B Chem. 2000, 43, 643-648.

95. Taylor, S.W.; Craig, A.G.; Fischer, W.H.; Park, M.; Lehrer, R.I. Styelin D, an extensively modified antimicrobial peptide from ascidian hemocytes. J. Biol. Chem. 2000, 275, 38417-38426.

96. Swersey, J.C.; Ireland, C.M.; Cornell, L.M.; Peterson, R.W. Eusynstyelamide, a highly modified dimer peptide from the ascidian Eusynstyela misakiensis. J. Nat. Prod. 1994, 57, 842-845.

97. McDonald, L.A.; Christopher Swersey, J.; Ireland, C.M.; Carroll, A.R.; Coll, J.C.; Bowden, B.F.; Fairchild, C.R.; Cornell, L. Botryllamides A-D, new brominated tyrosine derivatives from styelid ascidians of the genus Botryllus. Tetrahedron 1995, 51, 5237-5244.

98. Degnan, B.M.; Hawkins, C.J.; Lavin, M.F.; McCaffrey, E.J.; Parry, D.L.; van den Brenk, A.L.; Watters, D.J. New cyclic peptides with cytotoxic activity from the ascidian Lissoclinum patella. J. Med. Chem. 1989, 32, 1349-1354.

99. Hawkins, C.J.; Lavin, M.F.; Marshall, K.A.; van den Brenk, A.L.; Watters, D.J. Structure-activity relationships of the lissoclinamides: Cytotoxic cyclic peptides from the ascidian Lissoclinum patella. J. Med. Chem. 1990, 33, 1634-1638.

100. Donia, M.S.; Wang, B.; Dunbar, D.C.; Desai, P.V.; Patny, A.; Avery, M.; Hamann, M.T. Mollamides B and C, Cyclic hexapeptides from the indonesian tunicate Didemnum molle. J. Nat. Prod. 2008, 71, 941-945.

101. Carroll, A.R.; Bowden, B.F.; Coll, J.C.; Hockless, D.C.R.; Skelton, B.W.; White, A.H. Studies of Australian Ascidians. IV. Mollamide, a Cytotoxic Cyclic Heptapeptide from the Compound Ascidian Diplosoma virens. Aust. J. Chem. 1994, 47, 61-69.

102. Sonnenschein, R.N.; Farias, J.J.; Tenney, K.; Mooberry, S.L.; Lobkovsky, E.; Clardy, J.; Crews, P. A further study of the cytotoxic constituents of a milnamide-producing sponge. Org. Lett. 2004, 6, 779-782.

103. Coleman, J.E.; van Soest, R.; Andersen, R.J. New geodiamolides from the sponge Cymbastela sp. collected in Papua New Guinea. J. Nat. Prod. 1999, 62, 1137-1141.

104. Fusetani, N.; Sugawara, T.; Matsunaga, S.; Hirota, H. Orbiculamide A: A novel cytotoxic cyclic peptide from a marine sponge Theonella sp. J. Am. Chem. Soc. 1991, 113, 7811-7812.

105. Araki, T.; Matsunaga, S.; Nakao, Y.; Furihata, K.; West, L.; Faulkner, D.J.; Fusetani, N. Koshikamide B, a cytotoxic peptide lactone from a marine sponge Theonella sp. J. Org. Chem. 2008, 73, 7889-7894.

106. Pettit, G.R.; Cichacz, Z.; Barkoczy, J.; Dorsaz, A.C.; Herald, D.L.; Williams, M.D.; Doubek, D.L.; Schmidt, J.M.; Tackett, L.P.; Brune, D.C.; et al. Isolation and structure of the marine sponge cell growth inhibitory cyclic peptide phakellistatin 1. J. Nat. Prod. 1993, 56, 260-267. 
107. Pettit, G.R.; Tan, R.; Ichihara, Y.; Williams, M.D.; Doubek, D.L.; Tackett, L.P.; Schmidt, J.M.; Cerny, R.L.; Boyd, M.R.; Hooper, J.N. Antineoplastic agents, 325. Isolation and structure of the human cancer cell growth inhibitory cyclic octapeptides phakellistatin 10 and 11 from Phakellia sp. J. Nat. Prod. 1995, 58, 961-965.

108. Pettit, G.R.; Tan, R. Antineoplastic agents 390. Isolation and structure of phakellistatin 12 from a Chuuk archipelago marine sponge. Bioorg. Med. Chem. Lett. 2003, 13, 685-688.

109. Pettit, G.R.; Tan, R. Isolation and structure of phakellistatin 14 from the Western Pacific marine sponge Phakellia sp. J. Nat. Prod. 2005, 68, 60-63.

110. Davis, R.A.; Mangalindan, G.C.; Bojo, Z.P.; Antemano, R.R.; Rodriguez, N.O.; Concepcion, G.P.; Samson, S.C.; de Guzman, D.; Cruz, L.J.; Tasdemir, D.; Harper, M.K.; Feng, X.; Carter, G.T.; Ireland, C.M. Microcionamides A and B, Bioactive Peptides from the Philippine Sponge Clathria (Thalysias) abietina. J. Org. Chem. 2004, 69, 4170-4176.

111. Li, H.; Matsunaga, S.; Fusetani, N. Halicylindramides D and E, antifungal peptides from the marine sponge Halichondria cylindrata. J. Nat. Prod. 1996, 59, 163-166.

112. Rashid, M.A.; Gustafson, K.R.; Boswell, J.L.; Boyd, M.R. Haligramides A and B, two new cytotoxic hexapeptides from the marine sponge Haliclona nigra. J. Nat. Prod. 2000, 63, 956-959.

113. Bai, R.; Durso, N.A.; Sackett, D.L.; Hamel, E. Interactions of the sponge-derived antimitotic tripeptide hemiasterlin with tubulin: Comparison with dolastatin 10 and cryptophycin 1. Biochemistry 1999, 38, 14302-14310.

114. Crews, P.; Farias, J.J.; Emrich, R.; Keifer, P.A. Milnamide A, an unusual cytotoxic tripeptide from the marine sponge Auletta cf. constricta. J. Org. Chem. 1994, 59, 2932-2934.

115. Laird, D.W.; LaBarbera, D.V.; Feng, X.; Bugni, T.S.; Harper, M.K.; Ireland, C.M. Halogenated cyclic peptides isolated from the sponge Corticium sp. J. Nat. Prod. 2007, 70, 741-746.

116. Ratnayake, A.S.; Bugni, T.S.; Feng, X.; Harper, M.K.; Skalicky, J.J.; Mohammed, K.A.; Andjelic, C.D.; Barrows, L.R.; Ireland, C.M. Theopapuamide, a cyclic depsipeptide from a Papua New Guinea lithistid sponge Theonella swinhoei. J. Nat. Prod. 2006, 69, 1582-1586.

117. Bishara, A.; Rudi, A.; Aknin, M.; Neumann, D.; Ben-Califa, N.; Kashman, Y. Taumycins A and B, two bioactive lipodepsipeptides from the Madagascar sponge Fascaplysinopsis sp. Org. Lett. 2008, 10, 4307-4309.

118. Fusetani, N.; Warabi, K.; Nogata, Y.; Nakao, Y.; Matsunaga, S.; van Soest, R.R.M. Koshikamide A1, a new cytotoxic linear peptide isolated from a marine sponge, Theonella sp. Tetrahedron Lett. 1999, 40, 4687-4690.

119. Araki, T.; Matsunaga, S.; Fusetani, N. Koshikamide A2, a cytotoxic linear undecapeptide isolated from a marine sponge of Theonella sp. Biosci. Biotechnol. Biochem. 2005, 69, 1318-1322.

120. Boot, C.M.; Tenney, K.; Valeriote, F.A.; Crews, P. Highly $N$-methylated linear peptides produced by an atypical sponge-derived Acremonium sp. J. Nat. Prod. 2006, 69, 83-92.

121. Wesson, K.J.; Hamann, M.T. Keenamide A, a bioactive cyclic peptide from the marine mollusk Pleurobranchus forskalii. J. Nat. Prod. 1996, 59, 629-631.

122. Kimura, J.; Takada, Y.; Inayoshi, T.; Nakao, Y.; Goetz, G.; Yoshida, W.Y.; Scheuer, P.J. Kulokekahilide-1, a cytotoxic depsipeptide from the cephalaspidean mollusk Philinopsis speciosa. J. Org. Chem. 2002, 67, 1760-1767. 
123. Nakao, Y.; Yoshida, W.Y.; Takada, Y.; Kimura, J.; Yang, L.; Mooberry, S.L.; Scheuer, P.J. Kulokekahilide-2, a cytotoxic depsipeptide from a cephalaspidean mollusk Philinopsis speciosa. J. Nat. Prod. 2004, 67, 1332-1340.

124. Yu, Z.; Lang, G.; Kajahn, I.; Schmaljohann, R.; Imhoff, J.F. Scopularides A and B, cyclodepsipeptides from a marine sponge-derived fungus, Scopulariopsis brevicaulis. J. Nat. Prod. 2008, 71, 1052-1054.

125. Linington, R.G.; Edwards, D.J.; Shuman, C.F.; McPhail, K.L.; Matainaho, T.; Gerwick, W.H. Symplocamide A, a potent cytotoxin and chymotrypsin inhibitor from the marine Cyanobacterium Symploca sp. J. Nat. Prod. 2008, 71, 22-27.

126. Stolze, S.C.; Meltzer, M.; Ehrmann, M.; Kaiser, M. Solid phase total synthesis of the 3-amino-6-hydroxy-2-piperidone (Ahp) cyclodepsipeptide and protease inhibitor Symplocamide A. Chem. Commun. 2010, 46, 8857-8859.

127. Gutierrez, M.; Suyama, T.L.; Engene, N.; Wingerd, J.S.; Matainaho, T.; Gerwick, W.H. Apratoxin D, a potent cytotoxic cyclodepsipeptide from papua new guinea collections of the marine cyanobacteria Lyngbya majuscula and Lyngbya sordida. J. Nat. Prod. 2008, 71, 1099-1103.

128. Liu, L.; Rein, K.S. New peptides isolated from Lyngbya species: A review. Mar. Drugs 2010, 8, 1817-1837.

129. Andrianasolo, E.H.; Goeger, D.; Gerwick, W.H. Mitsoamide: A cytotoxic linear lipopeptide from the Madagascar marine cyanobacterium Geitlerinema sp. Pure Appl. Chem. 2007, 79, 593-602.

130. Maki, A.; Diwakaran, H.; Redman, B.; al-Asfar, S.; Pettit, G.R.; Mohammad, R.M.; al-Katib, A. The bcl-2 and p53 oncoproteins can be modulated by bryostatin 1 and dolastatins in human diffuse large cell lymphoma. Anticancer Drugs 1995, 6, 392-397.

131. Taraboletti, G.; Poli, M.; Dossi, R.; Manenti, L.; Borsotti, P.; Faircloth, G.T.; Broggini, M.; D'Incalci, M.; Ribatti, D.; Giavazzi, R. Antiangiogenic activity of aplidine, a new agent of marine origin. Br. J. Cancer 2004, 90, 2418-2424.

Samples Availability: Available from the authors.

(C) 2011 by the authors; licensee MDPI, Basel, Switzerland. This article is an open access article distributed under the terms and conditions of the Creative Commons Attribution license (http://creativecommons.org/licenses/by/3.0/). 